\title{
Movimento popular em Saúde Coletiva: saúde como prática de liberdade
}

Juliana Arruda

\section{Resumo}

O olhar amplo, considerando-se a complexidade do indivíduo, pautando-se a Determinação Social do Processo Saúde-Doença (DSPSD) a partir do recorte de classe, cor da pele, gênero e orientação sexual, nos auxilia a compreender a saúde e o adoecer, assim como guia a prática profissional em saúde. O Movimento Popular em Saúde Coletiva (MOPSC) encara a saúde por essa perspectiva, indo de encontro ao que ainda é expresso na maioria das Universidades tradicionais. O MOPSC surgiu por iniciativa de participantes de variados cursos do VER-SUS Edição Verão BH/2016, no dia 01/03/2016. O Movimento constrói-se conjuntamente pelas Ligas de Saúde Coletiva da Faculdade de Medicina da UFMG e Faculdade Ciências Médicas de Minas Gerais. Essa união de forças objetiva a construção de uma saúde verdadeiramente popular, multidisciplinar, em defesa do SUS e disposto a participar de sua construção e fortalecimento. Relatar objetivos, ações, parceiros e desafios do MOPSC, sugerindo exemplos para iniciativas semelhantes em outras Universidades brasileiras. Encontros quinzenais interdisciplinares, com a discussão de temas negligenciados em nossa formação; ações de extensão quinzenais ou mensais junto às comunidades das Ocupações Urbanas Eliana Silva e Izidora; atuação na construção e defesa do SUS; desenvolvimento de parcerias com movimentos sociais, sindicatos e movimentos estudantis. Os encontros interdisciplinares permitiram contato com assuntos como saúde da população privada de liberdade; saúde e a relação com identidade de gênero e a diversidade sexual; reforma psiquiátrica e luta antimanicomial; ocupações urbanas - democratização da cidade e saúde; atenção primária e planos de saúde; acompanhado de reflexão e desconstrução pessoal. As atividades de extensão visam à promoção de educação em saúde junto às comunidades das Ocupações Urbanas, por meio de rodas de conversa. Ao mediar o diálogo entre Hospital Sofia Feldman e as ocupações, foi possível garantir acompanhamento de pré-natal para todas as mulheres da comunidade e abertura para o debate sobre violência obstétrica e parto humanizado. A mediação com o Centro de Saúde próximo à Eliana Silva permitiu que a comunidade fosse atendida no local na ausência de endereço formal. Participação na organização e desenvolvimento do OcupaSUS BH; de encontros e atos contra o desmonte do SUS, o que estimula uma constante análise de conjuntura e autocrítica como usuários e futuros profissionais da saúde no SUS. Parceria com o Coletivo de Mulheres Alzira Reis, do Campus Saúde da UFMG, propiciou debater machismo e cultura do estupro e sua relação com a saúde integral da mulher dentro da Universidade. Reconhecemos as dificuldades em se desenvolver tal projeto. Há falta de recursos financeiros, limitando as atuações nas ocupações, principalmente pela dependência do transporte; não há material produzido para basearmos nossas ações; adesão aquém do desejado por parte dos estudantes e dificuldades em reconhecer nossas limitações na realidade das ocupações. Compreendemos que Saúde vai muito além da ausência de doença - ela é um processo multifacetado, determinado sociológica e historicamente. Há muito a se caminhar, mas sempre seguiremos a premissa: saúde é um fenômeno social!

Descritores: Saúde popular; Educação em saúde; SUS 